\title{
Music Education's “Legitimation Crisis” and its Relation to One-Dimensional Thinking
}

\author{
Paul Louth \\ Youngstown State University
}

This essay addresses behaviorism in music education and its possible connections to a kind of technicist thinking, first described by Herbert Marcuse, that ritualizes concepts and reduces them to a series of brute operations or behaviors. Labeled "technological rationalization" by early critical theorists, the mindset has potentially negative repercussions for education in general and music education specifically. I discuss the paradox of how we must grapple with increasing pressure to move toward a collapsed view of music's various and conflicting aesthetic and artistic meanings in our constant quest for curricular legitimacy in this era of objectives-based instruction.

Keywords: critical theory, behaviorism, legitimacy, legitimation crisis, technological rationalization, technology, functional, Marcuse, language.

One of the most important factors in the child's education ... is social adaptation. This means that-despite all the pretentious talk about the aims of education-it is not the child in and for himself who is being educated, but the child in and for society. And the society, moreover, is not an ideal one, with full justice and truth, but society as it is. (Jacques Ellul, The Technological Society)

I nstead of focusing on concrete examples of technology's role in music education, this essay will discuss behaviorism in music education, and its possible connections to a kind of technicist thinking, first described by Herbert Marcuse, that ritualizes concepts and reduces them to a series of brute operations or behaviors. This thought process was labeled "technological rationalization" by Marcuse and the critical theorists of the Frankfurt School, and the following is a discussion of its potential effects on the educational process writ large with some

(C) Paul Louth 2018. The content of this article is the sole responsibility of the author. The ACT Journal and the Mayday Group are not liable for any legal actions that may arise involving the article's content, including, but not limited to, copyright infringement. 
key examples from music education. In the second part of the essay I will discuss the paradox of how we must grapple with increasing pressure to collapse music's various and conflicting aesthetic and artistic meanings into its present functional meanings in our constant quest for curricular legitimacy in the present era of behavioral outcomes and "objective," assessment-driven instruction. Essentially, I will propose that such collapsing of conceptual musical meanings into functional meanings has potentially negative consequences for the aims of social justice in music education, and that increasing awareness of this process through questioning its effect on language in particular, should be given our top priority as a practical (although increasingly challenging) pursuit.

Marcuse referred to the world of thoughts and actions that people inhabit as "a universe of manipulated contradictions," by which he meant that ordinary language contains two levels of meaning: a metaphysical, or conceptual level and a concrete, context-bound level. The conceptual level refers to the entire collection of shared, historical meanings that are implied when a word is spoken or written, whereas concrete meanings are contingent insofar as they apply only to immediate cases. As David Ingram (1990) explains, the classical philosophers understood that words possess not only immediate, functional meanings, but also "universal" meanings that transcend the particular cases to which they apply. Although we may use the word "beauty" in specific ways to describe a flower, someone's personality, or a painting (and although the meaning will vary somewhat in each of these cases), there still exists a transcendent meaning that is triggered by the word's use, which, although difficult to specify, cannot be reduced to any particular context.

It is this "excess" meaning that allows ordinary language to function both ideologically and critically, according to Marcuse (1964), since there is an ongoing tension between the immediate, functional meaning of a word that applies in a given situation, and the conceptual, historical meanings that differ from the former. When we begin to (mis)use language in ways that erase this difference, all that remains are the functional meanings of words. Thus, users of language begin to mistake these operational meanings as the concrete and only meanings of words. Meaning is no longer considered contingent because there is no evident contradiction between the immediate meaning and any socially, historically, or culturally shared meanings that may transcend ways in which language is being used in the here and now. This "false concreteness" of concepts, by which they lose their transitive meaning, leads to uncritical modes of thought, since we surrender any conflicting definitions or explanations and accept immediate explanations of ing. Action, Criticism, and Theory for Music Education 17 (1): 9-32. doi:10.22176/act17.1.9 
concepts as permanent. Consequently, rather than inviting us to contemplate what is historically possible, language, thus treated, serves to adjust us to our immediate surroundings. In other words, language takes on a political function by blurring the difference between the way things are and the ways things might be.

Marcuse cites many examples of such blurring in One Dimensional Man, his treatise on the subject. These include the persistent way in which abstract nouns, such as "peace," "freedom," and "free market" are invested with fixed attributes that would normally be reserved for uncontroversial concepts that are grounded in nature. The repetitious and hypnotic presentation of such words in tandem with fixed images and oversimplified definitions promotes a set of "universally" accepted meanings that resist critique. In short, "the ritualized concept is made immune against contradiction" (88). One of the most pernicious forms of this practice in language involves accepted definitions in which "the criteria for judging a given state of affairs are those offered by ... [or] imposed by the given state of affairs" (115). In other words, if "democracy" (for example) is defined solely in terms of what occurs during present election cycles, we have predetermined, via circular reasoning, that elections must be democratic. As Marcuse puts it, the analysis becomes "locked" since "the range of judgment is confined within a context of facts which excludes judging the context within which the facts are made ...” (116).

If present meanings are contingent, however, this opens a world of possibilities for critiquing and possibly altering the present state of affairs. Ideology critique is essentially a means of uncovering the contingency of supposedly concrete meanings, and it has been the major project of critical theory, regardless of differences in approach. I consistently cite Marcuse, critical theorist of the Frankfurt School, because he was arguably the earliest scholar to paint a vivid picture of the role modern technology and mass media play in subverting ideology critique by encouraging such (mis)use of language.

Equating words with their functions, thereby obfuscating any tension or contradiction associated with their concepts, is a particular misuse of language that Marcuse dubs "one dimensional thinking." Elsewhere described as "positive thinking" by various critical theorists, it is thought to be directly connected (at the very least facilitated, if not caused) by an increasingly technologized society:

The tolerance of positive thinking is an enforced tolerance-enforced not by any terroristic agency but by the overwhelming, anonymous power and efficiency of the technological society. As such it permeates the general consciousness-and the consciousness of the critic. The absorption of the negative by the positive is 
validated in the daily experience, which obfuscates the distinction between rational experience and irrational reality. (Marcuse 1964, 226)

Marcuse argued that the advent of modern technology allowed for a shift away from personal dependency and toward dependency on rational systems. This process became known as technological rationalization and, although the roots of ideology critique lie in Western Marxism, by the late 1940s such "Marxist" scholars were in agreement that it was at the core of not only late-stage capitalism, but of all forms of political domination, including fascism and bureaucratic socialism (Ingram 1990).

This may seem like an overarching claim to make about technology, but a little reflection should suffice to reveal the extent to which rational systems can quietly exert control over mental processes. A good example of this is the cycle of selfblame that often accompanies our inability to learn to properly work some piece of technology. The psychologist-engineer and design expert Donald A. Norman is perhaps best known for helping people to understand that it is not their fault when they execute the wrong function while attempting to open a public door (pushing instead of pulling, for example), or when they find it frustrating to work "simple" electronic home appliances. He describes how poor technological design often results in a form of "taught helplessness," in which the user blames herself or himself for not being able to complete the task, rather than recognizing poor design as the cause for frustration and lack of execution (Norman 1988).

Norman explains that, when working with technology of any kind, ordinary people generally fail to account for various factors that allow for precise behavior to result from imprecise knowledge of an entire system. Such factors include transfer of knowledge from the mind to the world, along with the fact that great memory precision is not necessary to execute many routine tasks. For example, it is not necessary to remember the exact information on common coins in order to use them as currency; one need only superficially distinguish them from one another. Other factors include the presence of natural and cultural constraints. These are the physical limits of how certain objects, buttons, or switches can be manipulated, along with culturally learned facts about socially acceptable behaviors (children learn early on that coins should be spent and not eaten). Norman's point is that whether technology is "working well" for people or not, such design factors as affordances, cultural constraints, and the like tend to remain hidden to most people, 
causing them to imbue technology with a kind of unquestionable logic, or "rightness," which leads users to assume personal blame when common technologies are not easily mastered. In all of his examples, the presence of some seemingly rational system obscures the fact that human agency is always at work in the form of choices that designers of technologies make. The array of choices available to designers who decide how a particular technological function should present itself is not always easily recognized by the time that technology arrives at the marketplace in fully developed form. In other words, any sense of contingency can be easily masked by a technological function presenting itself as rational.

Norman's work concerns itself primarily with the effect that this peculiar modern problem has on people's attitudes toward technology use. That is to say it promotes a lack of critical thought with regard to the social origins of technological design, thereby suggesting an "all-or-nothing" stance so far as technology use goes. Marcuse and other critical theorists, however, go further in arguing that as technological integration increases in society, critical thought decreases, since technological reasoning tends to collapse conceptual, or contingent, meanings into purely functional meanings. It is in this way that technological reasoning "shapes the expression of a specific social and political behaviorism” (Marcuse 1964, 87).

\section{Behaviorism and Education}

Behaviorism is, of course, an apt description of what results when the conceptual realm is reduced to observable outcomes, or functions, so it is no coincidence that Marcuse chooses this word to describe the results of what he calls technological rationalization. The field of education, and in particular American public education, has seen several decades of well-documented movement toward "outcomesbased teaching," with its focus on assessable, that is, outwardly observable, learning objectives that align with official standards. Music education philosopher Øivind Varkøy (2007) claims that such pedagogical trends are antithetical to humanistic forms of education because they reduce human beings to "a causal system of stimulus and response; physiological urges and needs; or a product of the social and economic environment, respectively" (42).

He writes that behaviorism moves pedagogy in the direction of a "purely technical science with an everlasting search for new and better teaching methods" (42). The relationship between behaviorism and technicist thinking is explained by the 
necessity to eliminate all of the subjective (unobservable, and therefore unverifiable) aspects of human behavior in order to arrive at the behaviorist position. The purely mechanistic, or technical, is all that remains when one ignores all of the ambiguous and underdetermined aspects of what it means to be a person:

[I]f one believes that one can analyze human beings solely in terms of what is outwardly observable-body, action, and behavior, social roles, and so on-and does not consider human intentional consciousness, then one misses that which is specifically human. One is talking about a mechanism not a human being. (Varkøy 2007, 39)

As an alternative definition of (meaningful) learning, Varkøy suggests Rousseau's idea that education is modeled on free development, which leads to subjective autonomy, while teaching is a matter of setting the conditions for such development rather than molding the individual into, arguably, a mere object if the behaviorist model is embraced. Varkøy's discussion of learning as free growth versus molding is a philosophical one that reflects the long-standing debate over whether human nature is to be trusted (free growth) or distrusted (molding) by the educator; however, behaviorism in education also reflects the assumption that learning is an abstract process of transmission that happens within a culture that is itself not a functional part of the learning process. Following Vygotsky and later constructivists, most contemporary definitions of learning, developed in stark opposition to the abstract, transmission model, now acknowledge the "sociocultural nature of human cognition" (Kozulin 2004).

Varkøy is not positing that behavior, social roles, and other observable phenomena are not important to understand, or that they are not necessarily a part of education, but rather that if we stop our inquiries there, our categories of analysis will be far too simplistic to gain an adequate comprehension of what it means to be human. Interestingly, when discussing the negative implications of behaviorism that manifest as instrumentalism (or means-end thinking) in music education, he uses the term "multidimensional" to describe a humanistic philosophy that opposes such an objectivist stance (42). The word "multidimensional" perfectly describes a type of thinking about human behavior that includes those aspects of consciousness, such as intentionality, that transcend reductionist analysis. Conversely, Marcuse's "one-dimensional thinking” perfectly describes the opposite idea. The reduction of learning to mere observable, mechanistic behaviors can be

Louth, Paul. 2018. Music education's "legitimation crisis" and its relation to one dimensional thinking. Action, Criticism, and Theory for Music Education 17 (1): 9-32. doi:10.22176/act17.1.9 
seen as a symptom of one-dimensional thought, whereby the phrase "human learning” has been reduced to a series of functions, thus the phrase's conceptual and, therefore, controversial meanings, are lost.

Thinking back to Marcuse's examples of ritualized forms of language that lose conceptual meaning through mindless repetition, one is reminded of similar "catch phrases" and "buzz words" in education. The phrase "best practices" has become ubiquitous in higher education, such that undergraduates at my teaching institution come into contact with it several dozen times prior to graduating. In each case it is used in the same way that political propagandists use the term "democracy." To reiterate Marcuse's point, the present conditions serve as the definition, therefore critical analysis is locked out. Another linguistic example that Marcuse is fond of pointing out is the unification of opposites. Phrases such as "luxury fallout shelter" or "war to achieve peace" refer to opposite concepts that do not logically harmonize, yet, with adequate repetition, the tension between such opposing concepts vanishes. The juxtaposition of irreconcilable terms in the same phrase presents an artificially induced harmonization that resists critique.

Unification of opposites is no stranger to the field of education. For example, both standards-based learning outcomes and differentiated instruction are consistently taught and reinforced in a side-by-side manner. Recognizing their "seemingly competing imperatives," McTighe and Brown (2005) explain that "détente" is possible (and, they argue, necessary) through a "balanced" approach in which accommodating "differences in learners' readiness level(s), interests, and learning profiles" becomes a necessary prerequisite to helping them to meet standardized objectives. The authors maintain that "through this process, teachers decrease skills and knowledge gaps, as well as accommodate individual students' demonstrated strengths, interests, and personal learning goals" (236-7). In order to achieve this harmony, however, the phrase "personal learning goals" must clearly be understood to refer to personal preferences only for examples, pacing, or methods for acquiring the agreed-upon knowledge, as opposed to any real qualitative difference in what will count as the knowledge outcome itself. Any "personal" learning goals must not be so personal as to fail to align with the larger goals of the official standards. Here we have a case of functional language that leaves no room for any real contestation of its meaning.

Louth, Paul. 2018. Music education's "legitimation crisis" and its relation to one dimensional thinking. Action, Criticism, and Theory for Music Education 17 (1): 9-32. doi:10.22176/act17.1.9 


\section{Examples from Music Education}

The process I have been discussing, through which conceptual meanings may be collapsed into purely functional meanings, has significant implications not only for education in general but for music education in particular. An obvious example is the unquestioning attitude with which some North American music education practitioners and scholars proselytize certain music teaching methods (Regelski 2002, Woodford 2005, Louth 2014). In using the term "method," I refer to both senses of the general definition: (1) "a particular procedure for accomplishing or approaching something” and (2) "orderliness of thought or behavior" (OED). The first sense emphasizes the importance of both instrumentalism and behaviorism to method. A method exists in order to accomplish a particular goal or bring about

a desired outcome. Presumably, the faster, more efficiently, and more completely the outcome is achieved, the better the method.

Jenkins (2011) argues that such "rule-governed methods" that are often associated with technicism are thought to be an inherent part of formal teaching of any kind (although he actually uses a term similar to that coined by the early critical theorists to describe this ends-based thinking: "technical rationality"). Admitting that it may be an exaggeration to claim that an overreliance on technical approaches to music education would necessarily lead to students being unable to make decisions for themselves, Jenkins nevertheless says that "a focus on externally structured, incremental approaches certainly appears to reinforce following rules and doing things the right way in pursuit of the ends chosen" (183). Because formal education places so much emphasis on ends rather than means, the pragmatic aspect of methods should be of concern to the critical educator. The problems that methods set out to solve are technical, not ethical or philosophical (or, by extension one could argue, musical) in nature. ${ }^{1}$ Thus methods do not pose questions about the values underlying the framing of the (technical) problems they address. Because of this, the function of a teaching method may easily come to replace its conceptual content, and critical analysis may become "locked" as it were.

\section{The One-Dimensional Ensemble Rehearsal}

Evidence of the long history of functionalist-behaviorist thinking in North American school music programs can be found in various studies that have been done on the teaching of large performing ensembles, still the heart and soul of American music education. In keeping with this behaviorist model, centralized control and ing. Action, Criticism, and Theory for Music Education 17 (1): 9-32. doi:10.22176/act17.1.9 
design are exceptionally prominent features of such school music programs, as numerous studies over the years have attested. Worthy, describing his 2009 study on "expert teaching" in beginning band, uses the term "expert teachers" repeatedly to describe band directors leading successful rehearsals (29). This is only one of numerous studies on effective use of rehearsal time in which the terms "teaching" and "rehearsing" are used interchangeably, suggesting, at least in American contexts, a purely behaviorist concept of education in light of the array of rehearsal activities generally equated with teaching. Much of this literature is focused on "error detection" in students' performances (not to mention state-mandated teacher preparation tests, which also focus on error detection) and the desired outcome of such research is framed as bringing about "positive changes in student performance" (Cavitt 2003, 219).

In studies examining "effective" rehearsal techniques, student "performance" is assumed the best or only acceptable indicator of music learning. The concept of "correct" or "appropriate" performance is understood to equate with learning; however, it is difficult to see how this could translate into learning that is distinguishable from behavioral conditioning. Reporting on their own previous study comparing a high school honor band with an intercollegiate honor band, Worthy and Thompson (2009) note that all but $3 \%$ of rehearsal time studies was devoted to either conductor talking/modeling, or student performance. In their study of how three "expert teachers" use their instructional time in rehearsals, the authors note that approximately $64 \%$ of the time was devoted to teacher talk, with about $11 \%$ of time devoted to modeling, and the remainder of time spent eliciting student performance. In the study, there is no percentage of time devoted to student talk, feedback, or even responding to questions. Even more telling, the vast majority of teacher talk assumed the form of directives, with positive feedback, negative feedback, and information taking distant second, third, and fourth positions, and questioning being found nowhere in the rehearsal (36).

Goolsby's (1996) study of thirty high school "band directors" in an attempt to compare experienced and inexperienced educators uses some more hopeful language to describe "verbal instruction," which was one of the activities studied during the taped rehearsals. It is defined as "clarifying subject matter, teacher questioning, lecturing, conversations in which students and teachers interact, and giving instructions" (290). Unlike Worthy, Goolsby does not break down verbal instruction into subcategories so there is no way to know how much time the experienced teachers spent giving directives, as opposed to interacting with students ing. Action, Criticism, and Theory for Music Education 17 (1): 9-32. doi:10.22176/act17.1.9 
or posing questions; however, the experienced teachers spent the majority of the rehearsal time eliciting student performance, and very little time talking, compared to the less experienced teachers, which would seem to imply very little time that might be spent on any outcomes of a non-behaviorist variety.

In a 1996 study on "off-task behavior," Brendell used an observer to scan a choir and count the number of students who were off-task (8). The idea that it is possible to ascertain whether students are "on or off task" based on visually scanning is, of course, based on a behaviorist assumption that learning is evidenced through observable actions. This is the kind of learning, however, that more closely resembles conditioning than Rousseau's "free growth" model. It seems unlikely that such conditioning by itself would foster critical thinking abilities. Indeed, the instructional model for ensemble teaching in U.S. schools all but imposes behaviorist models of instruction owing to the large numbers involved (In most U.S. secondary schools, students experience their music learning in large, multi-age groups, most often not separated by grade level, although they may be separated by experience level or performing ability).

\section{Technological Rationalism and the Chase for Legitimacy}

The idea that music educators should find ways to expose students, through their teaching, to the many conflicting ideas in their field is certainly not new. George F. McKay made the suggestion sixty years ago, ${ }^{2}$ and it has been echoed more recently in various guises by Bowman (1991), Regelski (1998), Allsup (2001), Jorgensen (2003), and Woodford (2005) among others. Yet numerous scholars have commented on and/or critiqued a long-standing tendency of music teachers to adhere to rigid methods and sclerotic ways of thinking about music education (Colwell 2005, Woodford 2005, Jorgensen 2003, Regelski 1998, Knieter 1993). One compelling explanation for the apparent persistence of technical-rationalist thinking that defines musical concepts in terms of closed, functional language is the ongoing struggle for curricular legitimacy faced by music educators.

Technical-rationalist thinking tends to dominate the professions, a category in which teachers are always trying to show that they deserve membership. Schön (1987) writes that

Louth, Paul. 2018. Music education's "legitimation crisis" and its relation to one dimensional thinking. Action, Criticism, and Theory for Music Education 17 (1): 9-32. doi:10.22176/act17.1.9 
the relative status of the various professions is largely correlated with the extent to which they are able to present themselves as rigorous practitioners of a science-based professional knowledge and embody in their schools a version of the normative professional curriculum. ${ }^{3}$ (9)

In the field of education, an awareness of the correlation between legitimation and the appearance of rigorous, measurable norms that supposedly bestow an aura of scientific legitimacy arguably forms some part of what Glenn Nierman, Ken Zeichner, and Nikola Hobbel (2002) call "the professionalization agenda." Its advocates desire

an end to emergency teaching licenses, higher standards for entry to and exit from teacher education programs including performance-based assessments, external examinations of teacher content knowledge, mandatory national program accreditation, professional development schools, national board certification for teachers, and autonomous professional standards boards in each [U.S.] state. (821)

Yet, a considerable body of literature fails to support the idea that there is a correlation between the various professional standards that have been established in the field of music education and teaching effectiveness. In the absence of such a correlation, one must consider the strong possibility that it is what standards represent, rather than what they accomplish, that is important to the legitimation process in our field.

In a related vein, critical pedagogues David Purpel and Svi Shapiro (1995) argue that educators are made to believe that professionals concern themselves mainly with technical matters, unrelated to larger public issues such as sociology, philosophy, politics, etcetera. Because they tacitly accept this artificial distinction between the professional and the public domains, those who perceive themselves as professionals are more likely to sidestep crucial political, moral, or philosophical issues in favor of technical solutions to immediate problems. The educational philosopher Maxine Greene, writing in the late 1980s, shared these concerns about education's strong ties to what she called the "technicist" view, asserting that it is entirely at odds with "a concern for the critical and the imaginative" (Greene 1988, 126). Beynon (1998) similarly observes that "even the vocabulary of music education is problematic in that it is steeped in technical rationality with built-in hegemonic meanings" (100).

The increasing association of professions with technical issues that supposedly lie outside the public domain creates some immediate practical benefits for music educators, if music education is viewed this way. Specifically, there is enhanced ing. Action, Criticism, and Theory for Music Education 17 (1): 9-32. doi:10.22176/act17.1.9 
status and respect associated with any profession that appears to possess a unified body of knowledge that is (i) inaccessible to the general public and (ii) applicable to specific problems in its purview. This point dovetails with Benedict's (2006) assertion that attempts to promote the appearance of complete consensus by music educators are appeals for professional, rather than curricular, legitimacy. If educators as a group have an inferiority complex about their professional status, then music educators, who work in a field of "soft" knowledge in an era of shrinking budgets and disappearing programs, seem to have even more to prove. Unfortunately, professional aspirations that manifest themselves in this manner push the music education profession toward a mistaken view of knowledge as unified and discoverable in its entirety.

As a field of knowledge goes through the process of professional legitimation, it becomes increasingly fragmented, since specialization goes hand in hand with professionalization. Extreme professionalization and specialization breed technical, functional languages that focus on specific problems whose questions are often assumed to be preformed, that is, the way questions are formed is assumed to be given, and this limits the kinds of answers available. 4 Thus specialization distracts from the turbulent historical conditions that underpin knowledge. As Saul (1995) argues, "intellectual splintering" produces a gate-keeping system, complete with secret passwords (specialized dialects, impenetrable to outsiders) that ensures that one must "pass through the existing body of learning" in order to make any intellectual headway (178). The result is that integrated thought becomes extremely difficult. Saul believes that this explains, in part, the overwhelming passivity of many academics when it comes to pressing social concerns. He maintains that if the mind is allowed to prematurely narrow, particularly in the absence of a broad, humanities-based education, it is incapable of understanding the larger social and historical contexts out of which specialized knowledge emerges.

It seems that the more knowledge becomes fractured, the less likely we are to recognize its fractured state, a situation that is extremely problematic from the perspective of ideology critique. Rodney Miller, in a 1993 study of the administration of music programs in higher education, notes that specialization had already been steadily increasing over the years to the point that "knowledge that previously was a subset of traditional disciplines [had] grown to the level of a discipline or even been divided into several parts itself" (15). For example, the typical post-secondary music program is divided into various specialty areas (applied music, music theory, music history, music education, performing ensembles, music recording) that ing. Action, Criticism, and Theory for Music Education 17 (1): 9-32. doi:10.22176/act17.1.9 
are themselves subdivided into primary sub-sections (such as voice and keyboard) which subdivide further (piano, organ, harpsichord, etcetera).

Miller cites not only the expansion of knowledge but also the influence of business as a reason for the increasing compartmentalization within universities in general beginning in the late nineteenth century. In particular, prominent business leaders who made significant financial investments in schools felt that they could be improved by increasing their organizational planning and thus their efficiency. The introduction of modern, business-like administration accelerated departmental expansion and had the balkanizing effect of shifting loyalties "from the university community as a whole to the individual departments" (38).

As legitimation has been sought through specialization within the higher study of music, this must obviously be accompanied by a greater need for varying degrees of departmental allegiance, making it less likely that academics and music students will be able to integrate the specialized knowledge that they are accumulating and disseminating into a broader historical understanding. Closed disciplinary boundaries are impediments to understanding the socially constructed nature of many objective rules, forms, and ways of understanding. Specialized knowledge, when blocked off from larger realms of socio-historical meaning, appears pristine and untainted by conflict or doubt. A further point for consideration is that extremely specialized music programs (such as operatic performance, sound technician, music business, and, in an important sense, most music education programs) are generally geared to some aspect of the marketplace. Consequently, knowledge imparted in such programs is likely to be considered on the whole as a means to employment. And this instrumental aspect will render it somewhat immune from critique, thus reducing it to a purely functional level. Scheffler makes this point eloquently in saying that

the notion that education is an instrument for the realization of [utilitarian] social goals, no matter how worthy they are thought to be, harbors the greatest conceivable danger to the ideal of a free and rational society. For if these goals are presumed to be fixed in advance, the instrumental doctrine of schooling exempts them from the critical scrutiny that schooling itself may foster. $(1973,134)$

There is also a need to favor or rally around dominant epistemological views in order to gain curricular legitimacy, and this is another important factor that may lead to an inappropriate emphasis on technical or behavioral outcomes, resulting in one-dimensional thinking. The tendency to equate conflicting conceptual views 
with unhealthiness is attributable to a positivist, or rigidly structuralist epistemology, which is incompatible with critique, since such an outlook attributes a static hierarchy to knowledge when in actuality such "structures" are merely the historical sedimentations of socially constructed viewpoints. 5 This is simply another way of describing the problem of collapsing conceptual ideas into functional ideas, since the form of understanding that works best in the here and now becomes the fixed meaning to someone who only sees meaning as fixed.

Cherryholmes (1988), speaking of curriculum studies, has shown how a field that cannot come to consensus on key issues, definitions, and methods soon finds itself described in terms of metaphors relating to death and illness. Despite that conceptual turmoil and gray areas can and do "characterize all fields of study," lack of widespread agreement on foundational principles is generally considered to signify illness or death of a field of knowledge. In music education, a still relatively young field that is constantly fighting for legitimacy, the temptation will be to address the situation by striving to "unearth" a set of foundational principles that can be agreed upon more or less unanimously and permanently. As Jorgensen (2003) notes, the National Standards movement of the 1990 s was a perfect example of this type of reaction because it was "predicated on the notion that there is a universal structure [of knowledge] against which standards may be measured” (36). Standardization requires, by its very definition, a collapsing of multiple conceptual understandings into one unified (flattened out, in Marcuse's terms) concept. So, to circle back to the original focus, concerns for curricular legitimacy that call for standardization go hand in hand with one-dimensional, or technicist/behaviorist thought.

Another impediment to multi-dimensional thinking is the fact that professional programs, such as music educator preparation programs in higher education, must streamline information and maximize efficiency when preparing teachers for the marketplace. If conflicting theories, methods, approaches, or philosophies are brought to light, there will obviously be a much greater amount of information for students to deal with. Yet, in our current technically rationalized society, teachers may encounter students who have been pre-conditioned to believe that dealing with information means managing and digesting it, as opposed to carefully and critically sifting through it and making value judgments about what is appropriate. If a critical mindset has not been cultivated, dealing with information becomes a Herculean task unless presented as digestible and manageable. It is simply easier for someone who is unable to exercise critical judgment to ing. Action, Criticism, and Theory for Music Education 17 (1): 9-32. doi:10.22176/act17.1.9 
grasp onto a closed, monolithic belief system than to accommodate massive amounts of (often conflicting) information. In such cases, students may have already developed a yearning for completeness of knowledge and an understanding of fixed, universal structures, to which the critical educator may find it difficult not to submit.

Northrop Frye (1988) discusses this problem with regard to critical reading. He insists that the challenge should be met head on by educators, who should compel students to engage critically with information, since that is in fact the best way to assist them in dealing with overwhelming amounts of it. Frye stresses that it is crucial for educators to push students beyond passive, receptive modes of reading, which serve no critical function but merely create docile, obedient members of society. Insisting that "the elementary reader is trained above everything else to read things like traffic signs," Frye believes that

the art of reading has to be continued throughout life in order to keep presenting to the student the fact that reading is an active and creative process and that it is also a constant act of judgment. This sense of reading as an act of judgment lessens the panic that so many of us feel when we are confronted with the immense quantity of reading that there is to get through, the feeling that there are so many square miles of print that one needs just to keep up.... The act of reading as a continuous act of judgment is the key to equality and the key to freedom. Its purpose is the maintaining of the consistent consciousness which is the basis of human freedom and of human dignity. (100)

Although perhaps less politically charged, Frye's comments about critical reading are compatible with critical pedagogues' concerns about recent responses to the so-called crisis in literacy in North American education. Most reactions to (real or perceived) literacy problems seem to emphasize the development of a functional literacy, which serves the utilitarian interests of the marketplace. ${ }^{6}$ So long as society in general is convinced that the primary purpose of reading is functional, there will be a demand for knowledge that is presented in "neat and tidy" packages, free of conflict. And, related to the previous point, the need to grasp a fundamental underlying structure of knowledge is a logical consequence of this functionalist position.

Finally, one of the assumptions that seems to underpin our ongoing search for professional legitimacy is that professional candidates supposedly learn best from those professionals already practicing in the field, and minimally from "theoretical" coursework done in university settings, away from the "real world" of teaching.

Louth, Paul. 2018. Music education's "legitimation crisis" and its relation to one dimensional thinking. Action, Criticism, and Theory for Music Education 17 (1): 9-32. doi:10.22176/act17.1.9 
The increasing nation-wide (in the US) focus on state-mandated mentoring programs and pre-clinical field hours as a threshold for certification would appear to reinforce this message. On the opposite end of the spectrum, however, popular alternative certification models, such as Teach for America, draw candidates away from complex, theoretical work altogether. Candidates in TFA programs forgo traditional university preparation and, instead, typically take a five-week "crash course" before receiving the rest of their teacher education on the job, where they work with an experienced mentor teacher who is already teaching a full load of classes each day (Baines, 2010). The danger in all of this is that an overemphasis on praxis at the expense of, or divorced from, theory will turn education into mere technical training in the name of professional accountability. Notwithstanding the obvious importance of apprenticeship as a mode of authentic learning and the thousands of talented, thoughtful educators who serve as excellent role models for those entering the profession, if learning in the field is all that counts, knowledge of teaching consequently becomes reduced to the function of teaching, as it is currently done. In other words, rather than being encouraged to explore the various conceptual possibilities of what it might mean to teach music, the candidate's exposure is limited, in such a model, to whatever current "best practices" exist in the field.

Beynon (1998) notes that this technicist attitude already likely exists with regard to many music teacher candidates, owing to the strong, influential cultures that exists in many music programs in which $\mathrm{K}-12$ teachers acclimate their own students and their student teacher candidates to the profession. She cites research showing that students entering undergraduate teaching programs have already been exposed to an average of 15,000 hours of teaching. Predictably, this increases the likelihood that they "may be already socialized (perhaps unconsciously) to the norms and expectations of the profession" (83). In the case of music student teachers, Beynon observes that because they often report choosing their career path based on positive experiences in school settings, they "may be more acculturated to the norms of their profession than most" (83). Moreover, she points out that pre-service music teachers tend to value their practical experiences much more than their faculty courses, implying that technical expertise is perceived as paramount in relation to theoretical knowledge that may be unrelated to the "real" world of teaching. Unfortunately, this situation will generally work to reinforce the status quo, since overvaluing practical aims precludes "learning to think critically about learning to teach" (89). Beynon writes that

Louth, Paul. 2018. Music education's "legitimation crisis" and its relation to one dimensional thinking. Action, Criticism, and Theory for Music Education 17 (1): 9-32. doi:10.22176/act17.1.9 
the practicum site and, particularly, the cooperating teacher have a singularly critical impact on new teachers' practices in the beginning stages of their teaching careers and may in fact inhibit the latter from trying new forms of practice. (889, emphasis added)

In Beynon's own study of preservice music teachers, it was indeed the case that the associate teachers exerted "enormous influence over the practices of student teachers in the practicum," who basically conformed to the existing beliefs and practices of the environments in which they found themselves.7

\section{Concluding Thoughts}

Discussing the effects of rational systems on habits of mind clearly opens one to attack on the grounds that such effects are not wholly proven and, further, only an overly simplistic and deterministic position would assume that technological rationalization dulls everyone's critical senses equally. When reading the work of the first generation of critical theorists, and particularly Marcuse, one can easily interpret remarks about technology's effects on societal attitudes as being strongly determinist. But then one might ask, why bother alerting people to a potential problem if its effects are irreversible? This is an important point since, as pessimistic as critical theory may seem, its founders and followers tend not to be hard determinists. Quite the contrary-the idea of questioning the taken-for-granted definitions of words that we use and act on daily, in favor of opening up possibilities that may be otherwise blocked from conscious thought, is potentially quite liberating. To summarize, then, for purposes of this discussion technological rationalization (often identified as "technicism" in modern parlance) was defined as a type of reasoning that collapses conceptual knowledge into knowledge understood on a purely functional or behaviorist level, a process that hinders critical thought through blocking possible alternative definitions or explanations of commonly accepted concepts, such as "teaching," "rehearsing," "music learning," and the like.

To reiterate, I am not claiming that the examples offered here are necessarily typical of all that goes on in the North American music classroom or band hall. Instead, I am suggesting (notwithstanding the many exceptions that surely exist) that the combination of (1) a music education model based primarily on large performing ensembles, and (2) a profession in desperate need of curricular legitimacy, 
makes for a situation in which the kind of technicist/behaviorist thinking that Marcuse warned about certainly has the potential to predominate and block out critical thought and discussion among music educators. Because the central purpose of any teaching is arguably to instill habits of mind, music educators have the power to combat this potential effect simply by introducing alternative methods, explanations, and definitions of well entrenched constructs such as "successful ensemble director" or "effective music teacher," definitions that are inclusive of all cultural and musical values, not just western European musical values.

How might we move forward? Cloet and Shochet (1986), describing during the mid 1980 s what was then the increasingly behaviorist approach to teaching study skills at the university level, offer an intriguing analogy between study skills programs and clinical models, in which specialists diagnose and remedy problems. Because clinical models focus on behavioral outcomes, they tend to ignore the cognitive processes involved (for example, the authors describe typical clinical models of study skills remediation that ignore teaching how to determine which ideas or points are important, and instead focus on teaching elaborate note-taking and organizational skills). "Based on the scientific-medical approach to treatment, the paradigm is positivistic-technicist," they state. A cursory search of music education articles containing the words "error detection" or "diagnose" in the title will yield literally dozens written in the past twenty years. This lends credence to the popular metaphor of music teacher/ensemble director as a type of clinical first responder, a model that may be particularly apt in what Robinson calls the "hyper-competitive environment for instrumental music teaching and learning found in some places..." (2010).

Although there are certainly times when music educators will think of themselves as clinicians who perform interventions using a series of prescribed steps to diagnose and "fix" problems (i.e., symptoms), if such a technicist/behaviorist model is followed too often there will be no hope of focusing on the underlying processes that constitute true learning, since functional knowledge may replace conceptual understanding, including the necessary component of conceptual conflict. Cloet and Shochet argue that in order to overcome this problem, the teacher must see herself as an agent of social change. Somehow, the student must undergo a process of enlightenment as a result of our "interventions." One way to achieve this is through infusion, which is the model in which learning skills (not just techniques) are taught as part of the process of teaching the content. If music educators are accepting of the idea of conceptual conflict-the notion that there may, and in ing. Action, Criticism, and Theory for Music Education 17 (1): 9-32. doi:10.22176/act17.1.9 
fact probably does exist, more than one way to teach, to solve musical problems, to understand or hear musical ideas-as an integral part of their own learning, then that conceptual conflict may more easily become infused into their own lessons and rehearsal plans. But such an attitude must first be cultivated in university preparation programs by courageous educators who should present simultaneous alternative and competing viewpoints about music's structure, its teaching, its history, and its meaning. This constitutes doing direct battle with what Susan Wharton Conkling calls "the fixedness of musical understanding with which music students enter the collegiate environment" (2003).

How might music teachers challenge one-dimensional thinking in typical secondary music education settings, where it may be most difficult to avoid? In traditional American high school performance programs, lobbying for scheduling that allows for smaller numbers of students to be taught at one time is a rather mundane but obvious step that could help immensely. Having the means and administrative support to schedule rehearsals of extremely large ensembles before or after the curricular school day, and then seeing those same students broken down into more manageable numbers during class times would surely at least raise the prospects of introducing more questioning, alternative suggestions, definitions, or musical solutions into the performance setting. Aside from such logistical considerations, finding or being allowed the time to reflect on one's teaching practices is probably the most crucial means of avoiding technicist/behaviorist tendencies. Reynolds and Beitler (2007) note that the seemingly simple acts of reflection and collaboration can help to reframe long-held assumptions about music teaching practices. When reflective thought is critical in the best sense of the word, one reflects on one's practices and habits of mind in ways that are open to questioning assumptions, routine practices, and fixed ideas. True reflective thought, in the critical sense, is not pragmatic. That is, it does not immediately seek out practical solutions to technical problems; thus it can overcome the collapsing of concept and function, or what Marcuse calls the "pragmatic orientation" of everyday thinking that reinforces the status quo. Working to find ways to introduce epistemological conflict into the discourse of so-called best practices of music education is likely our best bet to ensure that technological rationalization does not have the last word. A possible first step toward raising awareness of this issue is to realize that, if we become tempted to buy our way into curricular and professional legitimacy 
by re-envisioning our knowledge base merely as a collection of methods for teaching observable behaviors and objective ideas, we risk impoverishing the very subject that we are trying so hard to protect.

\section{About the Author}

Paul Louth is Associate Professor of Music Education at Youngstown State University in Youngstown Ohio, U.S.A. where he teaches graduate and undergraduate courses in music education foundations, methods, and research. He is a former high school music teacher and professional freelance trombonist whose research interests focus on critical music pedagogy, philosophical issues in music education, music education technology, and informal music learning.

\section{References}

Allsup, Randall Everett. 2001. Music education as liberatory practice: Exploring the ideas of Milan Kundera. Philosophy of Music Education Review 9 (2): 310.

Benedict, Cathy. 2006. Chasing legitimacy: The US National Music Standards viewed through a critical theorist framework. Music Education Research 8 (1): $17-32$.

Baines, Lawrence A. 2010. The disintegration of teacher preparation. Educational Horizons 88 (3): 152-63.

Beynon, Carol. 1998. From music student to music teacher: Negotiating an identity. Studies in Music from The University of Western Ontario 17: 83-105.

Bowman, Wayne. 1991. A plea for pluralism: Variations on a theme by Georg McKay. In Basic concepts in music education II, edited by Richard Colwell, 94-110. Niwot, CO: University Press of Colorado.

Brendell, Janna K. 1996. Time use, rehearsal activity, and student off-task behavior during the initial minutes of high school choral rehearsals. Journal of Research in Music Education 44 (1): 6-14.

Carteledge, Paul. 1998. Classics: From discipline in crisis to (multi-)cultural capital. In Pedagogy and power: Rhetorics of classical learning, edited by Yun Lee Too and Niall Livingstone, 16-28. Cambridge, UK: Cambridge University Press.

Cavitt, Mary Ellen. 2003. A Descriptive analysis of error detection in instrumental music rehearsals. Journal of Research in Music Education 51 (3): 218-30.

Cherryholmes, Cleo H. 1988. Power and criticism: Poststructural investigations in education. New York: Teachers College Press.

Louth, Paul. 2018. Music education's "legitimation crisis" and its relation to one dimensional thinking. Action, Criticism, and Theory for Music Education 17 (1): 9-32. doi:10.22176/act17.1.9 
Cloet, Nico, and Ian Shochet. 1986. Alternatives to the behavioral technicist conception of study skills. Higher Education 15 (3/4): 247-58.

Colwell, Richard. 2005. Can we be friends? Bulletin of the Council for Research in Music Education 166: 75-91.

Conkling, Susan Wharton. 2003. Envisioning a scholarship of teaching and learning for the music discipline. College Music Society 43: 55-64.

Ellul, Jacques. 1964. The technological society. New York: Vintage Books. Originally published in French as La technique ou l'enjeu du siècle by Librarie Armand Colin, 1954.

Frye, Northrop. 1988. On education. Markham, ON, Canada: Fitzhenry and Whiteside.

Goolsby, Thomas W. 1996. Time use in instrumental rehearsals: A comparison of experienced, novice, and student teachers. Journal of Research in Music Education 44 (4): 286-303.

Greene, Maxine. 1988. The dialectic offreedom. New York: Teachers College Press.

Giroux, Henry A. 1988. Schooling and the struggle for public life: Critical pedagogy in the modern age. Minneapolis: University of Minnesota Press.

Ingram, David. 1990. Critical theory and philosophy. New York: Paragon.

Jenkins, Phil. 2011. Formal and informal music education practices. Philosophy of Music Education Review 19 (2): 179-97.

Jorgensen, Estelle R. 2003. Transforming music education. Bloomington, IN: Indiana University Press.

Knieter, Gerald L. 1993. Teaching and learning philosophy in the music education doctoral program. In Philosopher, teacher, musician: Perspectives on music education, edited by Estelle R. Jorgensen. University of Illinois Press.

Kozulin, Alex. 2004. Vygotsky's theory in the classroom: Introduction. European Journal of Psychology of Education 19 (1): 3-7.

Louth, J. Paul. 2014. There's madness in your method: A philosophical exploration into the thought of Paul Feyerabend and its implications for music education. British Journal of Music Education 31 (1): 69-83.

Marcuse, Herbert. 1964. One-dimensional man. Boston: Beacon Press.

McKay, George F. 1958. The range of music experience. In Basic concepts in music education, edited by Nelson B. Henry, 123-39. Chicago: The National Society for the Study of Education. 
McTighe, Jay and John L. Brown. 2005. Differentiated instruction and educational standards: Is détente possible? Theory into Practice 44 (3): 234-44.

Miller, Rodney. 1993. Institutionalizing music: The administration of music programs in higher education. Springfield, IL: Charles C. Thomas.

Nierman, Glenn E., Ken Zeichner, and Nikola Hobbel. 2002. Changing concepts of teacher education. In The new handbook of research on music teaching and learning, edited by Richard Colwell and Carol P. Richardson, 818-39. New York: Oxford.

Norman, Donald K. 1988. The design of everyday things. New York: Doubleday.

Pembrook, Randall, and Cheryl Craig. 2002. Teaching as a profession: Two variations on a theme. In The new handbook of research on music teaching and learning, edited by Richard Colwell and Carol P. Richardson, 786-817. New York: Oxford.

Postman, Neil. 1995. The end of education: Redefining the value of school. New York: Vintage Books.

Postman, Neil and Charles Weingartner. 1969. Teaching as a subversive activity. New York: Delacorte Press.

Purpel, David E. and Svi Shapiro. 1995. Beyond liberation and excellence: Reconstructing the public discourse on education. Westport, CT: Bergin and Garvey: 88

Regelski, Thomas A. 2002. On "methodolatry" and music teaching as critical and reflective practice. Philosophy of Music Education Review 10 (2): 102-123.

Regelski, Thomas A. 1998. Critical theory as a foundation for critical thinking in music education. Studies in music from the University of Western Ontario 17: $1-22$.

Reynolds, Alison M., and Nancy S. Beitler. 2007. Reflective practice in a middle school instrumental setting. Bulletin of the Council for Research in Music Education 173: 55-69.

Robinson, Mitchell. 2010. From the band room to the general music classroom: Why instrumentalists choose to teach general music. Bulletin of the Council for Research in Music Education 185: 33-48.

Saul, John Ralston. 1995. The Unconscious civilization. Concord, Ontario, Canada: House of Anansi Press.

Scheffler, Israel. 1973. Reason and teaching. London: Routledge and Keegan Paul.

Louth, Paul. 2018. Music education's "legitimation crisis" and its relation to one dimensional thinking. Action, Criticism, and Theory for Music Education 17 (1): 9-32. doi:10.22176/act17.1.9 
Schön, Donald A. 1987. Educating the reflective practitioner: Toward a new design for teaching and learning in the professions. San Francisco: Jossey-Bass Publishers.

Schön, Donald A. 1993. Generative metaphor: A perspective on problem-setting in social policy. In Metaphor and thought, 2nd edition, edited by Andrew Ortony, 137-63. New York: Cambridge University Press.

Varkøy, Øivind. 2007. Instrumentalism in the field of music education: Are we all humanists? Philosophy of Music Education Review 15 (1): 37-52.

Woodford, Paul. 2005. Democracy and music education: Liberalism, ethics, and the politics of practice. Bloomington, IN: Indiana University Press.

Worthy, Michael D. 2003. Rehearsal frame analysis of an expert wind conductor in high school vs. college band rehearsals. Bulletin of the Council for Research in Music Education 156: 11-19.

Worthy, Michael D. and Lane B. Thompson. 2009. Observation and analysis of expert teaching in beginning band. Bulletin of the Council for Research in Music Education 180: 29-41.

\section{Notes}

${ }^{1}$ Postman actually uses the term "metaphysical" to describe the kinds of problems that methods fail to address, thus placing him in league with the critical theorists who, the reader will recall, equated metaphysical problems with the conceptual realm which, they argued, was in danger of collapsing with the use of functional language and behaviorism.

2 McKay writes, "Most important ... is the presentation of a framework by which the student can understand and participate in the basic and stimulating philosophic ferment which permeates and energizes art creation in a healthy and democratic tolerant society.... This explanatory process is a particularly pertinent necessity to American education, since one of our basic tenets is freedom and willingness to allow philosophical ferment to operate within our artistic life, with no state-controlled value theory being imposed upon the creators of art." "The Range of Musical Experience," in Basic Concepts in Music Education, ed. Nelson B. Henry, 123-139 (Chicago: The National Society for the Study of Education, 1958), 132.

3 Interestingly, despite all the rhetoric about rigor and standards, the two most quantifiable criteria for entry into music teacher education programs, tests of musical skills and GPA, were not found to be reliable indicators of teaching success at the preservice level (Randall Pembrook and Cheryl Craig, "Teaching as a Profession," in The New Handbook of Research on Music Teaching and Learning, 801).

Louth, Paul. 2018. Music education's "legitimation crisis" and its relation to one dimensional thinking. Action, Criticism, and Theory for Music Education 17 (1): 9-32. doi:10.22176/act17.1.9 
4 Donald Schön demonstrates that certain professions are governed, for periods of time, by metaphors that cause professionals to assume the form in which questions dealing with major problems will be stated. For example, the metaphor SLUMS ARE DISEASES shaped many of the urban renewal policies of the 1950s because the problem was framed as an issue of health versus sickness. Thus in Schön's example the question, 'How shall we rid our otherwise healthy community of this blight?' would be an assumed starting point for solving the problem. This question is obviously limiting, however, as it fails to recognize the possibility that slums may alternatively be conceived as "natural communities." Donald A. Schön, "Generative Metaphor: A Perspective on Problem-solving in Social Policy," in Metaphor and Thought, $2^{\text {nd }}$ ed., ed. Andrew Ortony, 137-163 (New York: Cambridge University Press, 1993), 144-145. An additional problem with technical-rationalist approaches is that questions posed are often not sufficiently open-ended to allow for the generation of related questions. For education to be truly relevant, Postman and Weingartner argue, the questions we pose to students should always generate further questions. (Postman and Weingartner, 1969, 59-81).

5 As Jorgensen points out, this does not mean that we must abandon the idea of structures altogether. It simply means that their "dynamic nature" must be acknowledged, in light of which Jerome Bruner's early structural account of curriculum (as described in The Process of Education (Cambridge, MA: Harvard University Press, 1960)) is seen as "inadequate" $(2003,36)$.

${ }^{6}$ For example, Giroux writes, "The crisis in literacy is predicated on the need to train more workers for occupational jobs that demand 'functional' reading and writing skills. The conservative political interests that structure this position are evident in the influence of corporate and other groups on schools to develop curricula more closely tuned to the job market, curricula that will take on a decidedly vocational orientation (and in so doing reduce the need for corporations to provide on-the-job training)" (1998, 149).

7 An important difference between the context of Beynon's study and most American regions: in Ontario, the success of a student teacher's clinical experience is evaluated solely by the on-site mentor teacher, not by a team that includes the faculty representative of the degree-granting institution who comes to visit the site. This may provide additional incentive for pre-service teachers to conform to the beliefs and practices of teachers already in the system.

Louth, Paul. 2018. Music education's "legitimation crisis" and its relation to one dimensional thinking. Action, Criticism, and Theory for Music Education 17 (1): 9-32. doi:10.22176/act17.1.9 